\title{
Regulation of transferrin receptor synthesis by human cytotrophoblast cells in culture
}

\author{
M.J. Kroos, J.S. Starreveld, C.E.H. Verrijt, H.G. van Eijk, J.P. van Dijk* \\ Department of Chemical Pathology, Erasmus University Rotterdam, P.O. Box 1738, 3000 DR Rotterdam, The Netherlands
}

Received 27 September 1995; revision received 9 November 1995; accepted 28 November 1995

\begin{abstract}
The aim of this study was to examine the capacity of the syncytiotrophoblast to regulate transferrin receptor (TfR) synthesis in response to modulations in maternal iron supply. The model used was the primary trophoblast cell culture. Trophoblast cells isolated from term human placentas were cultured in iron-poor (Medium 199), iron-depleted (desferrioxamine (DFO)) and ironsupplemented (diferric transferrin (hTf-2Fe), ferric ammonium citrate (FAC)) medium. TfR synthesis was reduced in response to hTf-2Fe supplementation. FAC did not modulate TfR synthesis. Iron deprivation by DFO resulted in clear stimulation of TfR synthesis. These results show that the differentiating trophoblast cells respond to pertubations in the (transferrin-mediated) iron supply by adjustments in the rate of TfR synthesis. Taking syncytiotrophoblast in culture as model for the maternal/fetal interface in vivo, our results would suggest that the placenta is able to make short term adjustments of the capacity for iron uptake.
\end{abstract}

Keywords: Human; Syncytiotrophoblast; Transferrin; Receptor; Synthesis; Iron

\section{Introduction}

The growing fetus needs increasing amounts of iron. Maternal diferric transferrin ( $\mathrm{Tf}-2 \mathrm{Fe}$ ) is taken up by the placental syncytiotrophoblast by means of (transferrin) receptor mediated endocytosis [1]. After release of iron from the so formed endosomes to the cytosol, the endosomes recycle, fuse with the microvillous membrane and apo-Tf is set free into the maternal circulation. The processes involved in the subsequent transfer of iron through the cytosol and across the basal plasma membrane are unknown [1-3].

It was shown previously, that the increase of placental iron transfer during pregnancy is related to an increase of the number of transferrin receptors (TfR) on the expanding maternal/fetal interface. The Tf/TfR affinity is not affected [4].

What factors influence the number of TfRs? Placental

* Corresponding author, Fax: +31 10 4360615; email: vandijk@chepa.fgg.eur.nl. growth follows a developmental programme. This of course does not exclude the possibility that parameters like TfR density can, to some degree, be adjusted to the momentary needs. It is to be expected that the growing placenta responds to reductions in the maternal iron supply with an increase of the microvillous $T f R$ number or density. An increased maternal iron supply will probably induce a reduction of TfR number or density. These adjustments can in principle be achieved by TfR redistribution between cell interior and cell surface [5], and/or by adjustments in the rate of $T f R$ synthesis.

Using the primary culture of trophoblast cells from term human placentas $[6,7]$, we investigated the influences of iron supplementation and withdrawal on denovo TfR synthesis. It is shown that, conforming with the Iron Responsive Element (IRE) hypothesis [8-10], supplementation of the culture media with hTf-2Fe reduces, and iron withdrawal with DFO stimulates synthesis. Supplementation with anorganic ferricammoniumcitrate (FAC) has no effect. The results are discussed in the context of the regulation of placental iron transfer. 


\section{Materials and methods}

\subsection{Chemicals}

Calcium- and magnesium-free solutions of Eagle's balanced salts (EBBS), fetal calf serum (FCS), Dulbecco's modification of Eagle's medium with $20 \mathrm{mM}$ HEPES (DMEM-H), medium 199 (M199), penicillin, streptomycin and amphotericin were obtained from Flow Labs (ICN Biomedicals, Zoetermeer, Netherlands). Modified Eagle's medium without L-methionine and L-glutamine (MEM) was obtained from Gibco, UK; gentamicin was from Schering Corp., USA; trypsin (1:250 t.c.) was from Sigma Chemical Company, St Louis, USA and DNAse grade II was from Boehringer Mannheim, Germany; aprotinin, L-methionine and PMSF were from Sigma, USA; percoll was from Pharmacia, Upsala, Sweden and ${ }^{35}$ S-translabelled methionine was purchased from ICN Biomedicals, USA. Mouse anti-CD9 and goat anti-mouse IgG magnetic beads were purchased from DAKO (ITK Diagnostics BV, Uithoorn, Netherlands). All other chemicals and reagents (highest purity) were from commercial sources. Human (apo)transferrin (hTf) was obtained from Behringwerke (Marburg a.d. Lahn, Germany).

\subsection{Cytotrophoblast-cell isolation}

Human term placentas from pregnancies without complications were obtained from the Department of Obstetrics, University Hospital Rotterdam/Dijkzigt, within half an hour after spontaneous delivery. These placentas were processed according to [2] with slight modifications. Approximately $30 \mathrm{~g}$ villous tissue was preincubated for $10 \mathrm{~min}$ at $37^{\circ} \mathrm{C}$ with $50 \mathrm{ml}$ of the enzyme solution as used by [2]. The supernatant was discarded and the remaining villous tissue was digested following the original procedure [2]. Cells obtained were counted (using a Bürker counting-chamber) and diluted to $6 \times 10^{5}$ cells $/ \mathrm{ml}$ in culture medium (see further). This cell-suspension was plated out in 35-mm diameter Falcon culture dishes (Greiner and Söhne, Germany) at a density of $1.5 \times 10^{6}$ cells/dish. Culture medium consisted of $80 \% \mathrm{v} / \mathrm{v}$ M199; $20 \% \mathrm{v} / \mathrm{v}$ FCS; $4 \mathrm{mM} \mathrm{L-}$ glutamine; $0.3 \mathrm{mg} / \mathrm{ml}$ gentamicine; $50 \mathrm{IU} / \mathrm{ml}$ penicillin; $50 \mu \mathrm{g} / \mathrm{ml}$ streptomycin and $2.5 \mu \mathrm{g} / \mathrm{ml}$ amphotericin. Osmolarity was between 280 and $300 \mathrm{mosmol} / \mathrm{kg}, \mathrm{pH} \mathrm{7.4}$. The medium was sterilized by filtration on $0.22 \mu \mathrm{m}$ Millipore-GS filter (Millipore SA Molsheim, France). Cultures were incubated at $37^{\circ} \mathrm{C}$ in humidified $5 \%$ $\mathrm{CO}_{2} / 95 \%$ air.

\subsection{Cell culture conditions}

The cells in culture were allowed to recover from the isolation procedure for $24 \mathrm{~h}$. In order to remove nonadherent cells, the dishes were washed four times with 2 $\mathrm{ml}$ phosphate buffered saline (PBS). Cell culture was continued another $24 \mathrm{~h}$ in $1.5 \mathrm{ml}$ fresh culture medium before denovo synthesis of TfR was assessed. These fresh media were fortified with iron (hTf-2Fe (1.25 mM) or FAC $(10 \mu \mathrm{g} / 1))$ or iron depleted by means of $50 \mu \mathrm{M}$ DFO. Control series: M199 without additions.

\subsection{Transferrin receptor synthesis}

Cells were washed twice with PBS. Methionine-free medium was added and the cells were incubated for $1 \mathrm{~h}$ at $37^{\circ} \mathrm{C}$, followed by $2 \mathrm{~h}$ incubation with $60-80 \mu \mathrm{Ci}$ translabelled ${ }^{35} \mathrm{~S}$-methionine $(1089 \mathrm{Ci} / \mathrm{mmol})$ per $1.5 \times$ $10^{6}$ cells, also in methionine-free medium. The medium was removed and the cells were washed twice with $2 \mathrm{ml}$ PBS. The cells were lysed for $30 \mathrm{~min}$ at $4^{\circ} \mathrm{C}$ in $300 \mu \mathrm{l}$ lysate buffer consisting of 1\% Triton X-100, $1 \mathrm{mM}$ phenyl-methyl-sulfon-fluoride (PMSF) and $0.5 \mathrm{U} / \mathrm{ml}$ aprotinin in PBS pH 7.4. To recover all cell material the dishes were washed twice with $100 \mu 1$ lysate buffer. Lysis was checked using an inverted microscope. The celllysates were centrifuged for $2 \mathrm{~min}$ at $10000 \mathrm{~g}\left(\mathrm{r}_{\mathrm{av}} .5\right.$ $\mathrm{cm})$. Bovine serum albumin $(4 \mathrm{mg} / \mathrm{ml})$ and $\mathrm{L}$-methionine ( $10^{4}$ times the original ${ }^{35} \mathrm{~S}$-methionine concentration) were added to $300 \mu \mathrm{l}$ supernatant of all the samples. TfR precipitation was achieved with $50 \quad \mu l$ [hTf-2Fe]Sepharose-4B (Tf 100\% saturated with iron), followed by gentle rotation of the samples during $18 \mathrm{~h}$ at $4^{\circ} \mathrm{C}$. The samples were spun down $(5 \mathrm{~min}, 1000 \mathrm{~g})$ and the precipitates were washed four times with PBS containing $0.2 \%$ sodium-desoxycholate, $0.2 \%$ Triton $\mathrm{X}-100,1$ $\mathrm{mM}$ PMSF, and $1 \mathrm{mg} / \mathrm{ml}$ BSA. The final precipitates were boiled for $5 \mathrm{~min}$ with electrophoresis sample buffer (4 ml distilled water, $1 \mathrm{ml} 0.5 \mathrm{M}$ Tris- $\mathrm{HCl} \mathrm{pH} 6.8,0.8$ $\mathrm{ml}$ glycerol, $1.6 \mathrm{ml} 10 \% \mathrm{SDS}, 0.4 \mathrm{ml} 2 \beta$-mercaptoethanol, $0.2 \mathrm{ml}$ bromophenol blue), and centrifuged for $2 \mathrm{~min}$ at $10000 \mathrm{~g}\left(\mathrm{r}_{\mathrm{av}} .5 \mathrm{~cm}\right)$. The supernatants were electrophoresed under reducing conditions, (MiniProtean II Cell, Bio-Rad) using 10\% homogenous ready gels (Bio-Rad). After drying, the gels were exposed to Kodak X-OMAT AR film.

\subsection{Total protein synthesis}

To $0.02 \mathrm{ml}$ of the cell lysate, $0.1 \mathrm{ml}$ distilled water and $0.1 \mathrm{ml}$ ice-cold $20 \%$ trichloroacetic acid (TCA) was added. After $10 \mathrm{~min}$ on ice, the samples were centrifuged for $15 \mathrm{~min}$ at $1500 \mathrm{~g}$ and $4^{\circ} \mathrm{C}$. The precipitate was washed with $0.05 \mathrm{ml} \mathrm{10 \%}$ TCA and subsequently vigorously mixed with $0.5 \mathrm{ml}$ Soluene-350 (Packard). A sample of $0.02 \mathrm{ml}$ was carefully transferred to liquid-scintillation bottles, and $10 \mathrm{ml}$ Instagel (Packard) was added. After vigorous mixing and clearing up, the radiochemical concentration was measured in an Isocap 300 counter. 
Counting efficiency was always $>85 \%$. The amount of radiation (dpm) present in the total TCA precipitate was taken as a measure for total protein synthesis.

\subsection{Statistics}

The significance of the results was tested by using the Student-Newman-Keuls test $\left(\alpha_{T}<0.05\right)$. This test corrects the outcomes for multiple comparisons.

\section{Results}

A typical fluorogram is shown in Fig. 1. It demonstrates the influence of manipulation of the iron content of the culture media on denovo TfR synthesis. Notice that enrichment of the medium with hTf- $2 \mathrm{Fe}$ gives inhibition of the receptor synthesis, whereas supplementation with FAC is ineffective. Iron deprivation with DFO stimulates TfR synthesis.

The semiquantitive data obtained by laser-densitometry of the fluorograms are given in Fig. 2. Again, compared to the time controls, hTf-2Fe acts inhibitory, DFO stimulatory, and FAC does not seem to influence TfR synthesis. The data are expressed relative to total protein synthesis. Compared to both the control and the FAC series, TfR synthesis was significantly lower in the

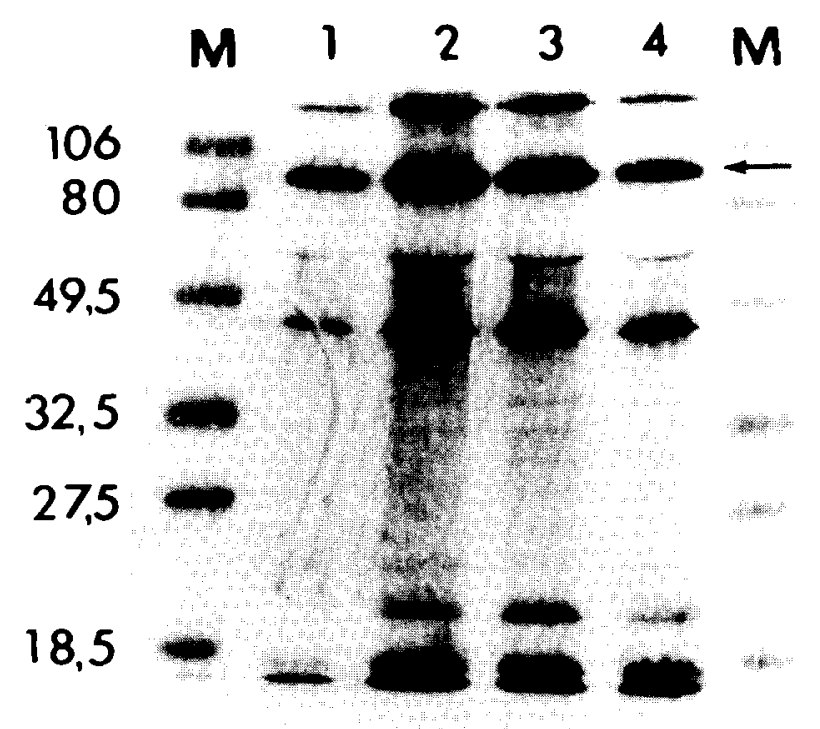

Fig. 1. Trophoblast transferrin receptor synthesis. Cells were isolated and cultured as described in materials and methods. TfR synthesis was assessed by ${ }^{35} \mathrm{~S}$-methionine pulse labelling and precipitation with [hTf-2Fe]-Sepharose-4B. After SDS-electrophoresis (reducing conditions) the gels were dried and exposed to $\mathrm{X}$-ray film. The monomeric form of the homodimeric TfR (mol - weight homomere: $90.000 \mathrm{kDal}$ ) is indicated by an arrow. Lane 1: $42 \mathrm{~h} \mathrm{hTf-2Fe} \mathrm{supplementation;} \mathrm{lane}$ 2: 42 h DFO supplementation; lane 3: 42 h FAC supplementation; lane 4: $42 \mathrm{~h}$ control. The results of one out of four representative experiments are shown.

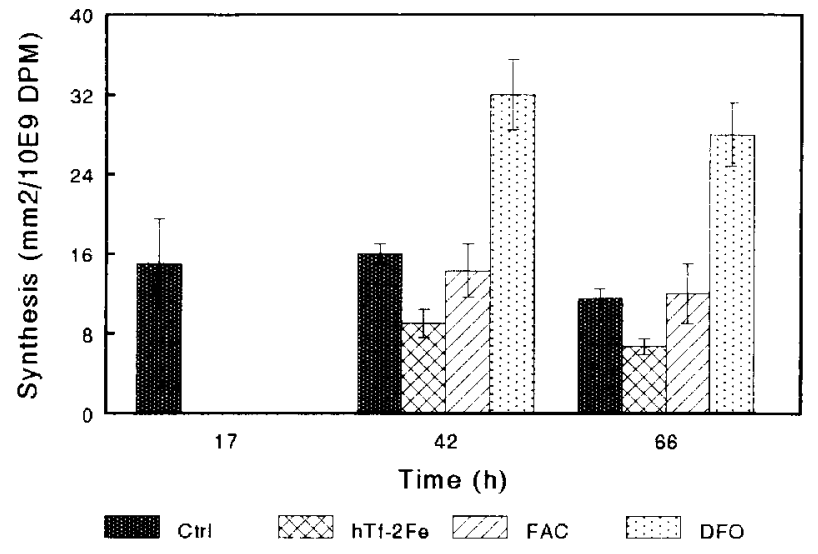

Fig. 2. Influence of culture time, iron supplementation and iron depletion on TfR synthesis. Quantification was achieved by densitometry of the developed films. The data are expressed relatively to total protein synthesis. Mean \pm S.D. of four independent experiments including one experiment with cells additionally immunopurified with anti-CD9 [14] are given.

hTf-2Fe series $\left(\alpha_{\mathrm{T}}<0.02\right)$, and significantly increased in the DFO series $\left(\alpha_{T}<0.001\right)$. Culture time did not affect $T f R$ synthesis.

\section{Discussion}

It was previously shown that cytotrophoblast cells in culture express TfRs and that the total number of TfRs as well as the number of surface TfRs increased with culture time $[2,5,7]$.

Expression of TfRs is part of the biochemical differentiation of the trophoblast cells towards syncytiotrophoblast or syncytiotrophoblast-like structures [7,12]. The total number of TfRs (as well as the surface TfR population) could, to some degree, be up- or downregulated, depending on the culture conditions with respect to iron depletion or iron supplementation $[5,13,14]$. This suggests that the differentiating trophoblast cell is able to adjust the rate of TfR synthesis to the momentary needs.

The results obtained in this investigation clearly prove that $T f R$ synthesis can be adaptively modified. Iron fortification of the culture media with hTf-2Fe reduced denovo TfR synthesis, whereas iron deprival with desferrioxamine (DFO) induced a stimulation. Supplementation with ferricammoniumcitrate (FAC) appeared to be ineffective.

For many cell types it was previously shown that adaptive change in the rate of both ferritin and TfR synthesis is regulated at the post-transcriptional level by iron. Increase of low molecular weight (lmw) iron in the cell stimulates the synthesis of ferritin and - at the same time - decreases TfR synthesis. Decrease of Imw-iron leads to the opposite events. These opposite effects of 
iron are explained by the Iron Responsive Element (IRE) hypothesis [8-10]. The effect of iron is mediated by an Iron Responsive Element Binding Protein (IREBP). This IRE-BP has $50 \%$ homology with mitochondrial aconitase [11]. In the presence of iron this protein has aconitase activity due to the $4 \mathrm{FeS}$ clusters formed. In the absence of iron no FeS-clusters can be formed and the protein looses its aconitase activity. At the same time binding of IRE-BP to the IREs on the mRNA of the ferritin (5'-untranslated region) and TfR (3'untranslated region) is enabled. This causes a reduction of ferritin synthesis and - at the same time - an increase of the TfR synthesis, due to improved stability of TfR mRNA. Reduction of intracellular lmw-iron leads to the reversed cascade.

In terms of the IRE hypothesis we would expect that hTf-2Fe is taken up easily, resulting in an increased lmw-iron concentration and an IRE sensitive reduction of TfR mRNA translation. The negative results obtained with FAC could be explained by a restricted availability of anorganic chelated iron. However, this explanation of the results fails. As previously shown the trophoblast cells take up FAC very rapidly, resulting in a clear increase in ferritin iron load and stimulation of denovo ferritin synthesis [14]. In contrast, supplementation of M199 with hTf- $2 \mathrm{Fe}$ only resulted in a marginal rise of the cellular iron content $[14,15]$, despite the fact that the rate of iron uptake from hTf-2Fe was about $80-110 \mathrm{pmol} / \mathrm{h} / \mathrm{mg}$ cell protein $[2,14,15]$. The absence of iron accumulation upon hTf-2Fe fortification, implicates iron release from the cells, without storage above the direct cellular needs $[14,15]$. In case of FAC supplementation, the syncytiotrophoblast is unable to keep intracellular iron low, and ferritin synthesis is stimulated.

The results suggest that the term syncytiotrophoblast can balance Tf mediated iron uptake and iron release. Reduction of surface TfRs by inhibition of denovo TfR synthesis may be one of the mechanisms involved in this regulatory process.

\section{References}

[1] van Dijk JP. Review article: regulatory aspects of placental iron transfer - a comparative study. Placenta 1988; 8: 347-354.

[2] Douglas GC, King BF. Uptake and processing of ${ }^{125}$ I-labelled transferrin and ${ }^{59} \mathrm{Fe}$-labelled transferrin by isolated human trophoblast cells. Placenta 1990; 11: 41-57.

[3] Harris ED. Brief critical review: new insights into placental iron transport. Nutr Rev 1992; 50: 329-337.

[4] van Dijk JP, van der Zande FGM, Kroos MJ, Starreveld JS, van Eijk HG. Number and affinity of transferrin-receptors at the placental microvillous plasma membrane of the guinea pig: influence of gestational age and degree of transferrin glycan chain complexity. J Dev Physiol 1993; 19: 221-226.

[5] Starreveld JS, van Dijk JP, Kroos MJ, van Eijk HG. Regulation of transferrin receptors expression and distribution in in vitro cultured human cytotrophoblasts. Clin Chim Acta 1993; 220: $47-60$.

[6] Kliman HJ, Nestler JE, Sernasi E, Sanger JM, Strauss III JF. Purification, characterisation and in vitro differentiation of cytotrophoblasts from human term placentae. Endocrinology 1986; 118: 1567-1582.

[7] Bierings MB, Adriaansen J, van Dijk JP. The appearance of transferrin receptors on cultures human cytotrophoblast and invitro formed syncytiotrophoblast. Placenta 1988; 9: 387-396.

[8] Kuhn LC, Hentze MW. Coordination of cellular iron metabolism by post-transcriptional gene regulation. J Inorg Biochem 1992; 47: 183-195.

[9] Melefors $\mathrm{O}$, Hentze $\mathrm{MW}$. Iron regulatory factor - the conductor of cellular iron regulation. Blood 1993; 7: 251-258.

[10] Mattia E, Renswoude J. The pivotal role of ferritin in cellular iron homeostasis. Bioassays 1988; 8: 107-111.

[11] Haile DJ, Raoult TA, Tang Chin J, Haford JB, Klausner RD. Reciprocal control of RNA-binding and aconitase activity in regulation of the iron responsive element binding protein: role of the iron-sulfur cluster. Proc Natl Acad Sci USA 1992; 89: 7536-7540.

[12] Bierings MB, Baert MRM, van Eijk HG, van Dijk JP. Transferrin receptor expression and the regulation of placental iron uptake. Mol Cell Biochem 1991; 100: 31-38.

[13] Bierings MB, van Eijk HG, Baert MRM, van Dijk JP. Regulation of transferrin receptor expression in term human cytotrophoblasts. Trophoblast Res 1992; 6: 237-248.

[14] Starreveld JS, Kroos MJ, van Suijlen JDE, Verrijt CEH, van Eijk HG, van Dijk JP. Ferritin in cultured human cytotrophoblasts: synthesis and subunit distribution. Placenta 1995; 16: 383-395.

[15] Starreveld JS, Kroos MJ, van Dijk JP, van Eijk, HG. The effects of iron supplementation on iron uptake by differentiating cytotrophoblasts. Reprod Fertil Dev 1996. Accepted for publication. 